\title{
Recovery of Acetylcholinesterase at Intact Neuromuscular Junctions After In Vivo Inactivation with Di-isopropylfluorophosphate ${ }^{1}$
}

\author{
HEDWIG KASPRZAK* AND MIRIAM M. SALPETER $\ddagger^{2}$
}

\begin{abstract}
* Institute of Arctic Biology, University of Alaska, Fairbanks, Alaska 99701 and $\ddagger$ Section of Neurobiology and Behavior, and School of Applied and Engineering Physics, Cornell University, Ithaca, New York 14853
\end{abstract}

\begin{abstract}
Recovery of acetylcholinesterase (AChE) at endplates of mouse sternomastoid muscle was studied after inactivation with di-isopropylfluorophosphate in vivo. A short incubation with $\alpha$-bungarotoxin was used to prevent muscle necrosis which usually occurs after esterase inactivation. Under these conditions there was no delay in AChE recovery, unlike what we had previously seen in necrotic muscle. However, even in non-necrotic muscle, the overall recovery of AChE at the postjunctional membrane was very slow, with a half-life of about $\mathbf{2 0}$ days. The fact that, at adult neuromuscular junctions, both esterases and receptors turn over about 10 times slower than they do in embryonic muscle suggests a similar regulation of these two molecules by the nerve.
\end{abstract}

Several studies have examined turnover of acetylcholinesterase (AChE) in brain (Chippendale et al., 1974; Wenthold et al., 1974; Yaksh et al., 1975; Grubic et al., 1981) and in muscle (Filogamo and Gabella, 1966; Inestrosa and Fernandez, 1977; Wooten and Cheng, 1980). Yet, to date, no study had quantitatively examined the turnover of AChE specifically at the postsynaptic region of the neuromuscular junction (NMJ) of uninjured vertebrate muscle. In an earlier study we found that, when the esterases at a mouse NMJ are inactivated, there is a delay of more than 3 days when no recovery of $A C h E$ can be seen. Thereafter the inactivated $A C h E$ recovers very slowly ( $t_{1 / 2}>20$ days) (Salpeter et al., 1979). Esterase inactivation, however, leads to muscle necrosis (Preussen, 1967; Fischer, 1968; Ariens et al., 1969; Fenichel et al., 1972; Laskowski et al., 1977; Hudson et al., 1978; Leonard and Salpeter, 1979; Salpeter et al., 1979, 1982). We wondered whether this necrosis, which lasts about 7 days under our conditions, could be responsible for either the initial delay or the subsequent slow AChE recovery. The present study therefore re-examined esterase recovery in muscles which were protected from necrosis by inactivation of the junctional acetylcholine receptors (AChRs) with $\alpha$-bungarotoxin ( $\alpha$ BTX) (Leonard and Salpeter, 1979; Salpeter et al., 1979).

We found that the initial delay in AChE recovery was indeed prevented in undamaged muscle; however, the recovery rate of $\mathrm{AChE}$ at the postjunctional folds was still slow, having an estimated half-life of about 20 days.

Received May 18, 1984; Revised September 5, 1984; Accepted September 11, 1984

\footnotetext{
${ }^{1}$ This work was supported by National Institutes of Health Grant NS 09315 We thank Maria Szabo and Rose Harris for technical assistance and Patricia Curran for typing the manuscript.

${ }^{2}$ To whom correspondence should be addressed, at Neurobiology \& Behavior, W 113 Mudd Hall, Cornell University, Ithaca, NY 14853.
}

\section{Materials and Methods}

Animal preparations for inactivating esterases. We used the sternomastoid muscle of the albino mouse (obtained from Blue Spruce Farms). Receptor and esterase inactivation was performed as previously described by Fertuck et al. (1975), Fertuck and Salpeter (1976), and Salpeter et al. (1979). Animals were anesthetized with Nembutal ( $50 \mathrm{mg}$ in $10 \%$ alcohol $/ \mathrm{kg}$ of body weight). The muscle was exposed and the nerve was stimulated with a suction electrode while muscle contractions were monitored with a needle electrode attached to an isotonic transducer. The exposed muscle was first bathed in $\alpha$-BTX $\left(10^{-6} \mathrm{M}\right.$ in Krebs' Ringer Solution) until the receptors were completely inactivated as judged by the fact that the muscle was unable to produce $a$ tetanic contraction (Fertuck et al., 1975). The esterases were then inactivated by di-isopropylfluorophosphate (DFP) $\left(10^{-3} \mathrm{M}\right)$ in Krebs' Ringer, $\mathrm{pH} 7.4$, applied topically to the muscle for 1.5 to $2.0 \mathrm{hr}$. Full esterase inactivation after such an incubation time was previously established (Salpeter et al., 1979 ) by the elimination of staining for esterases (Karnovsky and Roots, 1964) and by the loss in ability to sustain a tetanic contraction. After the double inactivation of receptors and esterases, the incision was closed and the animal was allowed to recover. The animals were reanesthetized 1,3 , or 7 days later and were perfused with phosphate-buffered $4 \%$ formaldehyde freshly prepared from paraformaldehyde, as described by Karnovsky (1965). The experimental sternomastoid muscle was cut into several longitudinal pieces and immersion fixed for an additional $3 \mathrm{hr}$ in fresh fixative, then stored in rinse buffer overnight.

Labeling of esterases. Pieces from each muscle were divided into three groups and incubated for labeling by one of the following procedures as previously described (Rogers et al., 1969). (1) To label all DFP-reactive sites we used ${ }^{3} \mathrm{H}$-DFP $\left(10^{-4} \mathrm{M}\right.$ in Krebs' Ringer, $\left.\mathrm{pH} 7.4,3.3 \mathrm{Ci} / \mathrm{mmol}\right)$ for $1 \mathrm{hr}$ at room temperature. (2) To label only AChE we used nonradioactive DFP (as above), followed by pyridine 2 -aldoxime methiodide (2-PAM) $\left(10^{-3} \mathrm{M}\right.$ in rinse buffer, $\mathrm{pH} 7.9$ ) at room temperature for $40 \mathrm{~min}$ to reactivate phosphorylated AChE (Wilson et al., 1958; Wilson and Froede, 1971), followed by ${ }^{3} \mathrm{H}-\mathrm{DFP}$ (as above). (3) To label all DFP-reactive sites except AChE we used ${ }^{3} \mathrm{H}-\mathrm{DFP}$ (as above) followed by 2-PAM (as above).

After the incubation sequences the tissue pieces were washed three times in rinse buffer (for a total of $15 \mathrm{~min}$ ), then in several washes of nonradioactive DFP $\left(10^{-3} \mathrm{M}\right.$ twice for $5 \mathrm{~min}$ and $10^{-4} \mathrm{M}$ three times for $\left.20 \mathrm{~min}\right)$ to remove nonspecific binding, and then left overnight in buffer

Autoradiography. Tissue blocks were postfixed in $1 \%$ aqueous $\mathrm{OsO}_{4}$, block stained in $2 \%$ uranyl acetate at room temperature, dehydrated, and embedded in Epon 812. Pale gold sections were cut, and their thickness was measured by an interferometer. Sections were then prepared for autoradiography by the "flat substrate" method of Salpeter and Bachmann (1964, 1972; for a detailed description of the technique, see also Salpeter, 1981), using a closely packed monolayer of llford L4 emulsion (deep purple to blue interference color). The slides were developed after a suitable time of exposure, calculated to give about 5 grains/end bouton for easy grain counting (28 to 486 days). Endplates in the developed autoradiograms were photographed in Philips 201 or 300 electron microscopes and enlarged in printing to $\times 20,000$. The grain density was obtained by first counting all grains in an area of emulsion expected to be exposed to radiation emanating from a radioactive line source coincident with the postiunctional membrane (PJM) (i.e., $0.5 \mu \mathrm{m}$ on the axonal side and $2.0 \mu \mathrm{m}$ on the muscle side of the axonal membrane). Background grains per unit area of autoradiogram were obtained over muscle at a distance from the junction and subtracted from the grains tabulated over the junction. The endplate grains, after background 
correction, were then divided by the surface area of the PJM measured in the autoradiograms (length of membrane times the measured thickness of section). This grain density was used to calculate sites per square micrometer of PJM as given in Salpeter et al., 1972.

\section{Results and Discussion}

Figure 1 illustrates an EM autoradiogram from muscle 7 days after inactivation with $\alpha$-BTX and nonradioactive DFP in vivo. The morphology of the muscle and endplates and the relative distribution of grains between the PJM and the Schwann cap appear normal. Similar normal morphology was seen at all times after inactivation with DFP due to the saturation of the receptors with $\alpha$-BTX. Table I gives the recovery of DFP-binding sites per square micrometer of PJM for the three labeling conditions. We found that, on the average, the fraction of total DFP-binding sites that are AChE (2-PAM reactivated) remains relatively constant (approximately one-fourth to onethird) during the recovery period examined. These ratios are similar to those in normal muscle (Rogers et al., 1969; Salpeter, 1969) and are in marked contrast to that seen during recovery in necrotic muscle (Salpeter et al., 1979), in which only about $6 \%$ of all new DFP-binding sites are AChE by day 7 .

Figure 2 plots the recovery of the three forms of DFP-binding sites on a semilogarithmic scale (as original sites minus newly labeled sites). Each curve gives a half-life of $\geq 20$ days.

Many studies have dealt with turnover of esterases (e.g., Davison, 1953; Koenig and Koelle, 1961; Inestrosa and Fernandez, 1977; Koelle et al., 1977a, b; Wooten and Cheng, 1980). Our study is the first to look quantitatively at the recovery of sites specifically at the PJM of intact NMJs in vivo. In an earlier study we found that, after inactivation with DFP, muscles become damaged and have a significant delay (between 3 and 7 days) before any new AChE (2PAM reactivatable) sites recover. Once recovery begins, however (at about 5 days), there is a recovery curve which extrapolates to a $t_{1 / 2}$ of about 20 days. In the present study we see that when muscle damage is prevented there is no delay in recovery of AChE (and there may in fact be a slight early acceleration of recovery), but the recovery rate itself is not much faster-again extrapolating to a $t_{1 / 2}$ of $\sim 20$ days.

There seems to be an interesting relationship between the turnover of $\mathrm{AChEs}$ and AChRs. In noninnervated chick muscles grown in culture, receptors turn over with a half life of $\sim 20 \mathrm{hr}$ and some esterases with a half-life of $\sim 50 \mathrm{hr}$ (Rotundo and Fambrough, 1980b). Thus, in noninnervated muscle, esterases turn over $\sim 2$ to 3 times slower than do receptors. Our current finding indicates that a similar relationship between the turnover time of esterases and receptors prevails at the innervated adult NMJ where the turnover rate of both molecules is slowed to the same extent (about 10-fold). After innervation, junctional receptors have a $t_{1 / 2}$ of 8 to 10 days (Berg and Hall, 1975; Chang and Huang, 1975; Burden, 1977; Heinemann et al., 1978; Reiness et al., 1978; Stanley and Drachmann, 1978; Loring and Salpeter, 1980; Michler and Sakmann, 1980; Levitt and Salpeter, 1981 ), and junctional esterases have a $t_{y / 2}$ of $\sim 20$ days (this study). Co-transport of receptors and esterases has been suggested for cultured muscle by Rotundo and Fambrough (1980a). The dramatic shift to a turnover rate that is $\sim 10$-fold slower at innervated junctions of both molecules suggests a similar regulation of these molecules by the nerve.

We have used 2-PAM reactivation (Wilson et al., 1958; Rogers et al., 1969) as a way to separate AChE from other DFP-binding sites. In normal muscle we consistently find that 2-PAM reactivates about $30 \%$ of the endplate sites (Rogers et al., 1969; Salpeter, 1969; Salpeter et al., 1972) and is the same fraction of sites protected by the specific AChE inhibitor, the Burroughs-Wellcome compound BW 284C51 (1,5-bis[4-allyl-dimethyl-ammonium-phenyl]pentane-3-one dibromide) (Rogers et al., 1969; Rotundo and Fambrough, 1980b). This emphasizes the fact that our labeling conditions during processing of the tissue successfully avoids the risk of DFP aging which could prevent reactivation with 2-PAM (Berends et al., 1959).

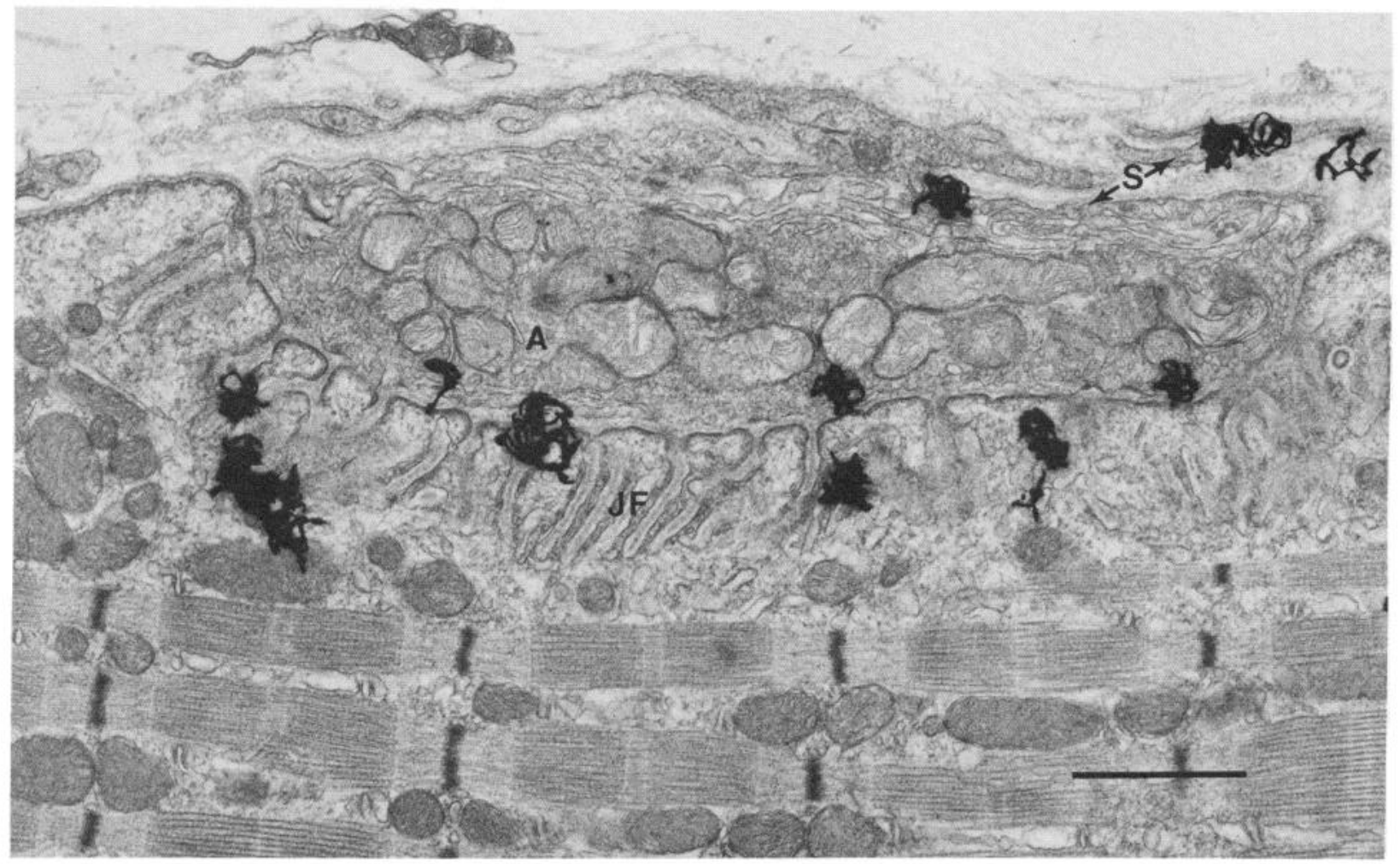

Figure 1. Autoradiogram showing distribution of ${ }^{3} \mathrm{H}$-DFP 7 days after inactivation of esterases by DFP. The distribution of developed grains is very much as seen in normal muscle although the site density is much reduced. (Muscle necrosis was prevented by pretreatment with $\alpha$-BTX.) Magnification $\times 20,000$. $A$, axon; $J F$, junctional fold; $S$, Schwann cell processes. 
TABLE I

Recovery of ${ }^{3} \mathrm{H}$-DFP binding sites at the PJM in endplates of sternomastoid muscle protected from myopathy

Muscles wcre protected from myopathy by pretreatment with a single dose of $\alpha$-BTX (Leonard and Salpeter, 1979; Salpeter et al., 1979), and all DFP reactive sites inactivated with nonradioactive DFP. New sites were labeled with ${ }^{3} \mathrm{H}$-DFP as indicated. Average site density is expressed as binding sites per square millimeter of membrane surface calculated as described previously (Salpeter et al., 1972). Double values indicate different animals. (For each animal, six different regions of the muscle were sampled and a total of 150 to 750 developed grains $[n]$ were obtained.) The percentage sampling error is $[\sqrt{n} / n] \times 100 \%$ or between 4 and $8 \%$.

\begin{tabular}{cccc}
\hline \multirow{2}{*}{\begin{tabular}{c} 
Time after $\begin{array}{c}\text { In Vivo Inactivation } \\
\text { (days) }\end{array}$ \\
\cline { 2 - 4 }
\end{tabular}} & \multicolumn{3}{c}{$\begin{array}{c}\text { 3H-DFP Binding } \\
\text { Site Densities }\end{array}$} \\
\cline { 2 - 4 } & Total Sites & AChE & Non-AChE \\
\hline 1 & ND $^{b}$ & 233 & 476 \\
7 & $1046 ; 1220$ & $208 ; 326$ & $478 ; 667$ \\
Normal $^{c}$ & $1412 ; 1703$ & $499 ; 562$ & $760 ; 1137$ \\
& $9560 \pm 710$ & $2660 \pm 400$ & $6600 \pm 830$ \\
\hline
\end{tabular}

${ }^{a}$ Total sites were all sites labled by ${ }^{3} \mathrm{H}-\mathrm{DFP}$. AChE (defined as 2-PAMreactivated sites) were obtained by incubation sequence DFP $\rightarrow 2$-PAM $\rightarrow$ ${ }^{3} \mathrm{H}-\mathrm{DFP}$; non-AChE sites were obtained by ${ }^{3} \mathrm{H}-\mathrm{DFP} \rightarrow 2$-PAM.

${ }^{b} \mathrm{ND}$, not determined.

' Values for normal animals were based on five to six animals obtained as above. Error ranges are standard error of mean.

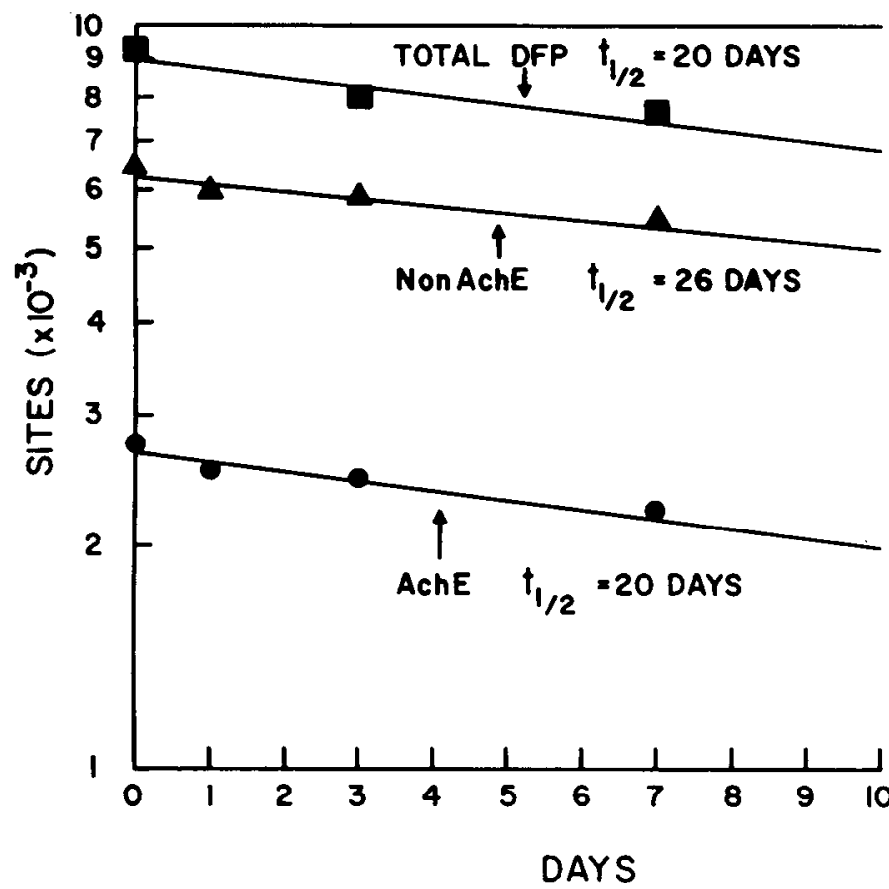

Figure 2. Recovery of esterases at mouse NMJs. AChE ( $)$, non-AChE $(\boldsymbol{\Delta})$, and total DFP ( $\square$ ) were labeled with ${ }^{3} \mathrm{H}$-DFP as described under Materials and Methods" after inactivation of all sites with nonradioactive DFP in vivo, and the site density of these newly labeled sites was assessed by EM autoradiography. (Values are derived by combining the values listed separately in Table 1.) The semilogarithmic plot was obtained by subtracting the newly labeled sites (at different times after inactivation) from the site density normally present (given as zero time value). Extrapolated curves and halflives were obtained by linear regression assuming that turnover follows firstorder kinetics. The three curves, which were obtained independently, show essentially the same recovery rate for both the AChE and non-AChE sites. This is in marked contrast to the situation reported previously (Salpeter et al., 1979) for muscle not protected from necrosis after esterase inactivation. In such necrotic muscle non-AChE sites have a much faster initial recovery rate than do AChE sites.
The nature of the DFP-binding sites not reactivated by 2-PAM or protected by BW $284 \mathrm{C} 51$ is not known. In the normal mouse muscle only about 10 to $30 \%$ of all DFP-binding sites are butyrylcholinesterase (BuChE) (Rogers et al., 1969; Barnard et al., 1971; H. Kasprzak and M. M. Salpeter, manuscript in preparation), and the rest (>40\%) are of as yet undetermined nature. The rather constant ratio of the different species of DFP-binding sites invites speculation on their functional relationship. After inactivation, these sites recover at the same rate in cultured chick muscle (Rotundo and Fambrough, 1980a) but at different rates in necrotic muscle (Salpeter et al., 1979). The present study shows that, if myopathy is prevented, the ratio of $A C h E$ to other DFP-binding sites remains constant during recovery. The delayed $\mathrm{AChE}$ synthesis and the uncoupling of its turnover from that of the other DFP-binding sites in damaged muscle are incompatible with the suggestion that BuChE is a precursor molecule for AChE (Koelle et al., 1977a, b; see also Edwards and Brimijoin, 1982).

The role of muscle in maintenance of junctional AChE is not yet resolved. Although synthesis of AChE by noninnervated muscle has been described (Brzin and Majcen-Tkacev, 1963; Tennyson et al., 1973; Sawyer et al., 1976; Golder et al., 1978; Rotundo and Fambrough 1980a, b; Brockman et al., 1982), other studies claim that muscle may contribute only a small portion of the junctional AChE compared to axonally transported material (e.g., Wooten and Cheng, 1980). In our experiments the nerve was left intact in the studies both with and without $\alpha$-BTX protection from muscle damage, yet, in the studies in which the muscle was damaged by the esterase inactivation (Salpeter et al., 1979), there was a delay in AChE recovery of about 3 to 7 days which corresponds to the peak period of damage. This strongly suggests that the muscle is a major contributor to the junctional $A C h E$, although the nerve is clearly important in regulating endplate AChEs (Filogamo and Gabella, 1966; Guth et al., 1966; Guth, 1968; Drachman, 1972; Hall, 1973; Vigny et al., 1976; Koenig and Vigny, 1978; Rubin et al., 1980; Weinberg et al., 1981), both via induced muscle activity (Giacobini et al., 1973; Rubin et al., 1980; Lømo and Slater, 1978, 1980) and via nerve factors (Guth et al., 1966; Guth, 1969; Lentz, 1972; Oh, 1976; Davey et al., 1979; Fernandez et al., 1979; Younkin et al., 1982).

As has been cited above, muscle activity may control AChE synthesis, although the extent of this control is not yet fully clarified, especially in adult muscle (e.g., Guth, 1969; Collins and Younkin, 1982). Therefore, there can be a concern that $\alpha$-BTX could affect recovery of $A C h E$ by eliminating muscle activity. But we only gave one dose of $\alpha$-BTX, and the ability to obtain neurally induced muscle contraction recovers to some extent already by 2 days after such an $\alpha$-BTX treatment (Fertuck et al., 1975), even though relatively few of the inactivated AChRs have turned over at that time $(\sim 15 \%$ by 2 days) (Loring and Salpeter, 1980). With esterases reduced, muscle activity recovers even more quickly. We therefore assume that muscle inactivity is not the cause for the slow recovery of $A C h E$ in the present study. The rapid recovery of some nerve-induced muscle activity may in fact raise the question as to why muscle necrosis does not develop in our $\alpha$-BTX-pretreated muscle since relatively few esterase molecules have recovered during the first 2 days $(\sim 10 \%)$. However, an explanation may come from the "saturating disk" model of neuromuscular response formulated in several publications from our laboratory (Fertuck and Salpeter, 1976; MatthewsBellinger and Salpeter, 1978; Salpeter and Land, 1980; Land et al., 1980, 1981; Salpeter, 1983). According to this model, even if AChR site density is low, muscle response will occur provided each quantum of ACh can spread over a large enough postsynaptic area to activate a sufficiently large number of receptors. The ratio of esterases to receptors then becomes crucial in determining the minimum AChR site density at which muscle contraction will occur. Since the AChEs recover at almost the same rate as do the receptors, a balance of AChE to AChR is maintained over the postsynaptic surface during recovery. This should allow an adequate 
number of receptors to be activated to produce muscle contraction while providing for a sufficiently rapid hydrolysis of the ACh after unbinding. Repeated reactivation of receptors would thus be prevented, eliminating the cause of the necrosis in the absence of esterases (Leonard and Salpeter, 1979).

It is well known that denervation causes a drastic drop in junctional AChE activity with a half-life of $\sim 1$ to 2 days and that this drop seems to be under neurotrophic control (Davey and Younkin, 1978; Fernandez et al., 1979; Ranish et al., 1980; Collins and Younkin, 1982). If, as we claim here, AChEs at innervated NMJs are replaced with a half-life of $\sim 20$ days, denervation could not cause the drop in junctional $A C h E$ merely by turning oft $A C h E$ synthesis. Denervation must therefore cause an acceleration of $A C h E$ degradation, possibly due to proteolytic enzymes released from degenerating nerve, to which the esterases in the neuromuscular cleft should be very sensitive (Hall and Kelly, 1971; Betz and Sakmann, 1971, 1973; McMahan et al., 1978). This suggestion is compatible with the finding that a longer distal nerve stump delays both the onset of nerve degeneration (e.g., Lømo, 1976) and the rapid drop in postdenervation junctional esterases (Fernandez et al., 1979; Ranish et al., 1980; Collins and Younkin, 1982).

In conclusion, the data presented here suggest that, normally, the turnover rate of junctional AChE is very slow. We do not know the physiological significance of the fact that, at the innervated NMJ, the turnover rate of esterases is slowed to the same extent as is that of the receptors. It may insure stability and a relatively constant ratio of $A C h E$ to $A C h R$, which is very important for maintaining normal neuromuscular function.

\section{References}

Ariens, A. Th., E. Meeter, O. L. Woltheus, and R. M. J. Van Benthan (1969) Reversible necrosis at the end-plate region in striated muscles of the rat poisoned with cholinesterase inhibitors. Experientia 25: 57-59.

Barnard, E. A., J. Wieckowski, and T. H. Chiu (1971) Cholinergic receptor molecules and cholinesterase molecules at mouse skeletal muscle junctions. Nature 234: 207-209.

Berends, F., C. H. Posthumus, I. van der Sluys, and F. A. Deierkauf (1959) Chemical basis of the "ageing process" of DFP-inhibited pseudocholinesterase. Biochim. Biophys. Acta 34: 576-578.

Berg, D. K., and Z. W. Hall (1975) Increased extrajunctional acetylcholine sensitivity produced by chronic post-synaptic neuromuscular blockade. J. Physiol. (Lond.) 244: 659-676.

Betz, W., and B. Sakmann (1971) 'Disjunction' of frog neuromuscular synapses by treatment with proteolytic enzymes. Nature 232: 94-95.

Betz, W., and B. Sakmann (1973) Effects of proteolytic enzymes on function and structure of frog neuromuscular junctions. J. Physiol. (Lond.) 230: 673-688.

Brockman, S. K., R. J. Przybylski, and S. G. Younkin (1982) Cellular localization of the molecular forms of acetylcholinesterase in cultured embryonic rat myotubes. J. Neurosci. 2: 1775-1785.

Brzin, M., and Z. Majcen-Tkacev (1963) Cholinesterase in denervated endplates and muscle fibers. J. Cell Biol. 19: 349-358.

Burden, S. (1977) Acetylcholine receptors at the neuromuscular junction: Developmental change in receptor turnover. Dev. Biol. 61: 79-85.

Chang, C. C., and M. C. Huang (1975) Turnover of junctional and extrajunctional acetylcholine receptors of the rat diaphragm. Nature 253: 643-644.

Chippendale, T. J., C. W. Cotman, M. D. Kozar, and G. S. Lynch (1974) Analysis of acetylcholinesterase synthesis and transport in the rat hippocampus: Recovery of acetylcholinesterase activity in the septum and hippocampus after administration of dilsopropylfluorophosphate. Brain Res. 81: 485-496.

Collins, P. L., and S. G. Younkin (1982) Effect of denervation on the molecular forms of acetylcholinesterase in rat diaphragm. J. Biol. Chem. 257: 1363813644.

Davey, B., and S. G. Younkin (1978) Effect of nerve stump length on cholinesterase in denervated rat diaphragm. Exp. Neurol. 59: 168-175.

Davey, B., L. H. Younkin, and S. G. Younkin (1979) Neural control of skeletal muscle cholinesterase: A study using organ-cultured rat muscle. J. Physiol. (Lond.) 289: 501-515.

Davison, A. N. (1953) Return of cholinesterase activity in the rat after inhibition by organophosphorus compounds. I. Diethyl $p$-nitrophenyl phosphate $(E$ 600, Paraoxan). Biochem. J. 54: 583-590.
Drachman, D. B. (1972) Neurotrophic regulation of muscle cholinesterase: Effects of botulinum toxin and denervation. J. Physiol. (Lond.) 226: 619627.

Edwards, J. A., and S. Brimijoin (1982) Divergent regulation of acetylcholinesterase and butyrylcholinesterase in tissues of the rat. J. Neurochem. 38: 1393-1403.

Fenichel, G. M., W. B. Kibler, W. H. Olson, and W. -D. Dettbarn (1972) Chronic inhibition of cholinesterase as a cause of myopathy. Neurology 22: $1026-1033$.

Fernandez, H. L., M. J. Duell, and B. W. Festoff (1979) Neurotrophic control of $16 \mathrm{~S}$ acetylcholinesterase at the vertebrate neuromuscular junction. $\mathrm{J}$. Neurobiol. 10: 441-454.

Fertuck, H. C., and M. M. Salpeter (1976) Quantitation of junctional and extrajunctional acetylcholine receptors by electron microscope autoradiography after ${ }^{125} \mid-\alpha$-bungarotoxin binding at mouse neuromuscular junctions. J. Cell Biol. 69: 144-158.

Fertuck, H. C., W. W. Woodward, and M. M. Salpeter (1975) In vivo recovery of muscle contraction after $\alpha$-bungarotoxin binding. J. Cell Biol. 66: 209213.

Filogamo, G., and G. Gabella (1966) Cholinesterase behaviour in the denervated and reinnervated muscles. Acta Anat. 63: 199-214.

Fischer, G. (1968) Inhibierung und restitution der azetylcholinesterase an der motorischen Endplatte im zwerchfell der Ratte nach intoxikation mit soman. Histochemie 16: 144-149.

Giacobini, G., G. Filogamo, M. Weber, P. Boquet, and J. -P. Changeux (1973) Effects of a snake alpha-neurotoxin on the development of innervated skeletal muscle in chick embryo. Proc. Natl. Acad. Sci. U. S. A. 70 . 1708-1712.

Golder, T. K., P. S. Nieberg, and B. W. Wilson (1978) Ultrastructural localization of acetylcholinesterase in cultured cells. III. DFP treated embryo muscle. J. Histochem. Cytochem. 26: 719-728.

Grubic, Z., J. Sketelj, B. Klinar, and M. Brzin (1981) Recovery of acetylcholinesterase in the diaphragm, brain, and plasma of the rat after irreversible inhibition by soman: A study of cytochemical localization and molecular forms of the enzyme in the motor end plate. J. Neurochem. 37: 909-916.

Guth, L. (1968) "Trophic" influences of nerve on muscle. Physiol. Rev. 48: 645-687.

Guth, L. (1969) Effect of immobilization on sole-plate and background cholinesterase of rat skeletal muscle. Exp. Neurol. 24: 508-513.

Guth, L., A. A. Zalewski, and W. C. Brown (1966) Quantitative changes in cholinesterase activity of denervated sole plates following implantation of nerve into muscle. Exp. Neurol. 16: 136-147.

Hall, Z. W. (1973) Multiple forms of acetylcholinesterase and their distribution in endplate and non-endplate regions of rat diaphragm muscle. J. Neurobiol. 4: 343 .

Hall, Z., and R. B. Kelly (1971) Enzymatic detachment of endplate acetylcholinesterase from muscle. Nature 232: 62-63.

Heinemann, S., J. Merlie, and J. Lindstrom (1978) Modulation of acetylcholine receptor in rat diaphragm by anti-receptor sera. Nature 274: 65-68.

Hudson, C. S., J. E. Rash, T. N. Tiedt, and E. X. Albuquerque (1978) Neostigmine induced alterations at the mammalian neuromuscular junction. II. Ultrastructure. J. Pharmacol. Exp. Ther. 205: 340-356.

Inestrosa, N. C., and H. L. Fernandez (1977) is there a correspondence between half-lives of motor endplate acetylcholinesterase and junctional acetylcholine receptors? Neurosci. Lett. 5: 91-93.

Karnovsky, M. J. (1965) A formaldehyde-glutaraldehyde fixative of high osmolarity for use in electron microscopy. J. Cell Biol. 27: 137a.

Karnovsky, M. J., and L. Roots (1964) A "direct-coloring" thiocholine method for cholinesterases. J. Histochem. Cytochem. 12: 219-221.

Koelle, G. B., W. A. Koelle, and E. G. Smyrl (1977a) Effects of inactivation of butyrylcholinesterase on steady state and regenerating levels of ganglionic acetylcholinesterase. J. Neurochem. 28: 313-319.

Koelle, W. A., E. G. Smyrl, G. A. Ruck, V. E. Siddons, and G. B. Koelle (1977b) Effects of protection of butyrylcholinesterase on regeneration of ganglionic acetylcholinesterase. J. Neurochem. 28: 307-311.

Koenig, E., and G. B. Koelle (1961) Mode of regeneration of acetylcholinesterase in cholinergic neurons following irreversible inactivation. J. Neurochem. 8: 169-188.

Koenig, J., and M. Vigny (1978) Neural induction of the 16 S acetylcholinesterase in muscle cell cultures. Nature 271: 75-77.

Land, B. R., E. E. Salpeter, and M. M. Salpeter (1980) Acetylcholine receptor site density affects the rising phase of miniature endplate currents. Proc. Natl. Acad. Sci. U. S. A. 77: 2293-2298.

Land, B. R., E. E. Salpeter, and M. M. Salpeter (1981) Kinetic parameters for 
acetylcholine interaction in intact neuromuscular junction. Proc. Natl. Acad. Sci. U. S. A. 78: 7200-7204

Laskowski, M. B., W. H. Olson, and W. -D. Dettbarn (1977) Initial ultrastructural abnormalities at the motor endplate produced by a cholinesterase inhibitor. Exp. Neurol. 57: 13-33.

Leonard, J. P., and M. M. Salpeter (1979) Agonist-induced myopathy at the neuromuscular junction is mediated by calcium. J. Cell Biol. 82: 811-819.

Lentz, T. L. (1972) Development of the neuromuscular junction. III. Degeneration of motor end plates after denervation and maintenance in vitro by nerve explants. J. Cell Biol. 55: 93-103.

Levitt, T. A., and M. M. Salpeter (1981) Denervated endplates have a dual population of junctional acetylcholine receptors. Nature 291: 239-241.

Lømo, T. (1976) The role of activity in the control of membrane and contractile properties of skeletal muscle. In Motor Innervation of Muscle, S. Thesleff, ed., Academic, New York, pp. 289-321.

Lømo, T., and C. R. Slater (1978) Control of acetyicholine sensitivity and synapse formation by muscle activity. J. Physiol. (Lond.) 275: 391-402.

Lømo, T., and C. R. Slater (1980) Control of junctional acetylcholinesterase by neural and muscular influences in the rat. J. Physiol. (Lond.) 303: 191202.

Loring, R., and M. M. Salpeter (1980) Denervation increases turnover rate of junctional acetylcholine receptors. Proc. Natl. Acad. Sci. U. S. A. 77: 22932298.

Matthews-Bellinger, J., and M. M. Salpeter (1978) Distribution of acetylcholine receptors at frog neuromuscular junctions with a discussion of some physiological implications. J. Physiol. (Lond.) 279: 197-213.

McMahan, U. J., J. R. Sanes, and L. M. Marshall (1978) Cholinesterase is associated with the basal lamina at the neuromuscular junction. Nature 271: $172-174$.

Michler, A., and B. Sakmann (1980) Receptor stability and channel conversion in the subsynaptic membrane of the developing mammalian neuromuscular junction. Dev. Biol. 80: 1-17.

Oh, T. H. (1976) Neurotrophic effects of sciatic nerve extracts on muscle development in culture. Exp. Neurol. 50: 376-386.

Preussen, H. -J. (1967) Die ultrastruktur der motorischen Endplatte in zwerchfell der Ratte und Veranderungen nach inhibierung der acetylcholinesterase. Z. Zellforsch. 80: 436-457.

Ranish, N. A., W. -D. Dettbarn, and L. Wecker (1980) Nerve stump lengthdependent loss of acetylcholinesterase activity in endplate regions of rat diaphragm. Brain Res. 191: 379-386.

Reiness, C. G., C. B. Weinberg, and Z. W. Hall (1978) Antibody to acetylcholine receptor increases degradation of junctional and extrajunctional receptors in adult muscle. Nature 274: 68-70.

Rogers, A. W., A. Darzynkiewicz, K. Ostrowski, M. M. Salpeter, and E. A. Barnard (1969) Quantitative studies on enzymes in structures in striated muscles by labeled inhibitor methods. I. The number of acetylcholinesterase molecules and other DFP-reactive sites at motor endplates measured by radioautography. J. Cell Biol. 41: 665-685.

Rotundo, R. L., and D. M. Fambrough (1980a) Secretion of acetylcholinesterase: Relation to acetylcholine receptor metabolism. Cell 22: 595-602.

Rotundo, R. L., and D. M. Fambrough (1980b) Synthesis, transport and fate of acetylcholinesterase in cultured chick embryo muscle cells. Cell 22: 583-594.

Rubin, L. L., S. M. Schuetze, C. L. Weil, and G. D. Fischbach (1980) Regulation of acetylcholinesterase appearance at neuromuscular junctions in vitro. Nature 283: 264-267.

Salpeter, M. M. (1969) Electron microscope radioautography as a quantitative tool in enzyme cytochemistry. II. The distribution of DFP-reactive sites at motor endplates of a vertebrate twitch muscle. J. Cell Biol. 42: 122-134.
Salpeter, M. M. (1981) High resolution autoradiography. In Techniques in the Life Sciences. Vol. I, Part 1: Techniques in Cellular Physiology, P. F. Baker, ed., pp. 1-45, Elsevier-North Holland Scientific Publishers Ltd., County Clare, Ireland.

Salpeter, M. M. (1983) Molecular organization of the neuromuscular synapse. In Myasthenia Gravis, E. X. Albuquerque and A. T. Eldefrawi, eds., pp. 105-129, Chapman and Hall, New York.

Salpeter, M. M., and L. Bachmann (1964) Autoradiography with the electron microscope. J. Cell Biol. 22: 469-477.

Salpeter, M. M., and L. Bachmann (1972) Electron microscope autoradiography. In Principles and Techniques of Electron Microscopy, Biological Applications, Vol. 2, M. A. Hayat, ed., pp. 221-278, Van Norstrand Reinhold, New York.

Salpeter, M. M., and B. R. Land (1980) Physiological consequences of ACh receptor and esterase distribution in vertebrate endplates. In Fondation Singer-Polignac, Colloque Claude Bornard, La Transmission Neuromusculaire, E. Wolff, ed., pp. 101-110, Masson S. A., Paris.

Salpeter, M. M., H. Plattner, and A. W. Rogers (1972) Quantitative assay of esterases in end plates of mouse diaphragm by electron microscope autoradiography. J. Histochem. Cytochem. 20: 1059-1068.

Salpeter, M. M., H. Kasprzak, H. Feng, and H. Fertuck (1979) Endplates after esterase inactivation in vivo: Correlation between esterase concentration, functional response and fine structure. J. Neurocytol. 8: 95-115.

Salpeter, M. M., J. P. Leonard, and H. Kasprzak (1982) Agonist-induced postsynaptic myopathy. Neurosci. Comment. 1: 73-83.

Sawyer, H. R., T. K. Golder, P. S. Nieberg, and B. W. Wilson (1976) Ultrastructural localization of acetylcholinesterase in cultured cells. I. Embryo muscle. J. Histochem. Cytochem. 24: 969-978.

Stanley, E. F., and D. B. Drachmann (1978) Effect of myasthenic immunoglobulin on acetylcholine receptors of intact mammalian neuromuscular junctions. Science 200: 1285-1287.

Tennyson, V. M., M. Brzin, and L. T. Kremzner (1973) Acetylcholinesterase activity in the myotube and muscle satellite cell of the fetal rabbit: An electron microscopic, cytochemical and biochemical study. J. Histochem. Cytochem. 21: 634-652.

Vigny, M., J. Koenig, and F. Rieger (1976) The motor end-plate specific form of acetylcholinesterase: Appearance during embryogenesis and re-innervation of rat muscle. J. Neurochem. 27: 1347-1353.

Weinberg, C. B., J. R. Sanes, and Z. W. Hall (1981) Formation of neuromuscular junctions in adult rats: Accumulation of acetylcholine receptors, acetylcholinesterase, and components of synaptic basal lamina. Dev. Biol. 84: 255-266.

Wenthold, A. J., H. R. Mahler, and W. J. Moore (1974) Properties of acetylcholinesterase from rat brain. J. Neurochem. 22: 945-949.

Wilson, I. B., and H. C. Froede (1971) The design of reactivators for irreversibly blocked acetylcholinesterase. In Drug Design, E. J. Ariens, ed., Vol. 2, pp. 213-229, Academic Press, Inc., New York.

Wilson, I. B., S. Ginsberg, and C. Quan (1958) Molecular complimentariness as basis for reactivation of alkyl phosphate inhibited enzyme. Arch. Biochem. Biophys. 77: 286-296.

Wooten, G. F., and C. - H. Cheng (1980) Transport and turnover of acetylcholinesterase and choline acetyltransferase in rat sciatic nerve and skeletal muscle. J. Neurochem. 34: 359-366

Yaksh, T. L., M. G. Filbert, W. Harris, and H. I. Yamamura (1975) Acetylcholinesterase turnover in brain, cerebrospinal fluid and plasma. J. Neurochem. 25: 853-860.

Younkin, S. G., L. H. Younkin, M. Zoller, and C. Rosenstein (1982) Partial purification by vacuum distillation of a factor that increases the junctional acetylcholinesterase of organ cultured rat diaphragm. Brain Res. 249: 192-194. 